\title{
Accountability entre os representantes de organizações civis que atuam nos Conselhos Gestores
}

Olívia Cristina Perez ${ }^{1}$

\section{Resumo}

Cada vez mais organizações civis assumem tarefas de representação, expondo e defendendo causas e grupos sociais perante o Estado e outras instituições. Contudo, as práticas de representação dos trabalhadores de organizações civis, incluindo suas relações de accountability, ainda são pouco conhecidas. Contribuindo com os estudos nessa área, examinamos neste artigo aspectos das relações de accountability envolvidas nas práticas de representantes de organizações civis que atuam nos Conselhos Gestores de Políticas Públicas. Constatamos que não há acordos formais e instituições capazes de impulsionar a accountability dos representantes, nos moldes daqueles que existem nas arenas parlamentares. Contudo, novas relações de accountability são estabelecidas pelos trabalhadores de organizações civis que atuam nas áreas afetadas pelas decisões dos Conselhos.

Palavras-chave: Accountability. Representação. Organizações civis. Conselhos Gestores.

\section{Introdução}

$\mathrm{N}$ as últimas décadas a atuação de organizações civis vem ganhando espaço nas esferas governamentais: projetos do governo podem ser executados por meio do estabelecimento de

1 Professora titular da Universidade Paulista (UNIP/Santos). Doutora em Ciência Política pela Universidade de São Paulo (FFLCH/São Paulo), mestre em sociologia pela mesma instituição e graduada em Ciências Sociais pela Universidade Estadual Paulista "Júlio de Mesquita Filho" (FCLAr/Araraquara). 


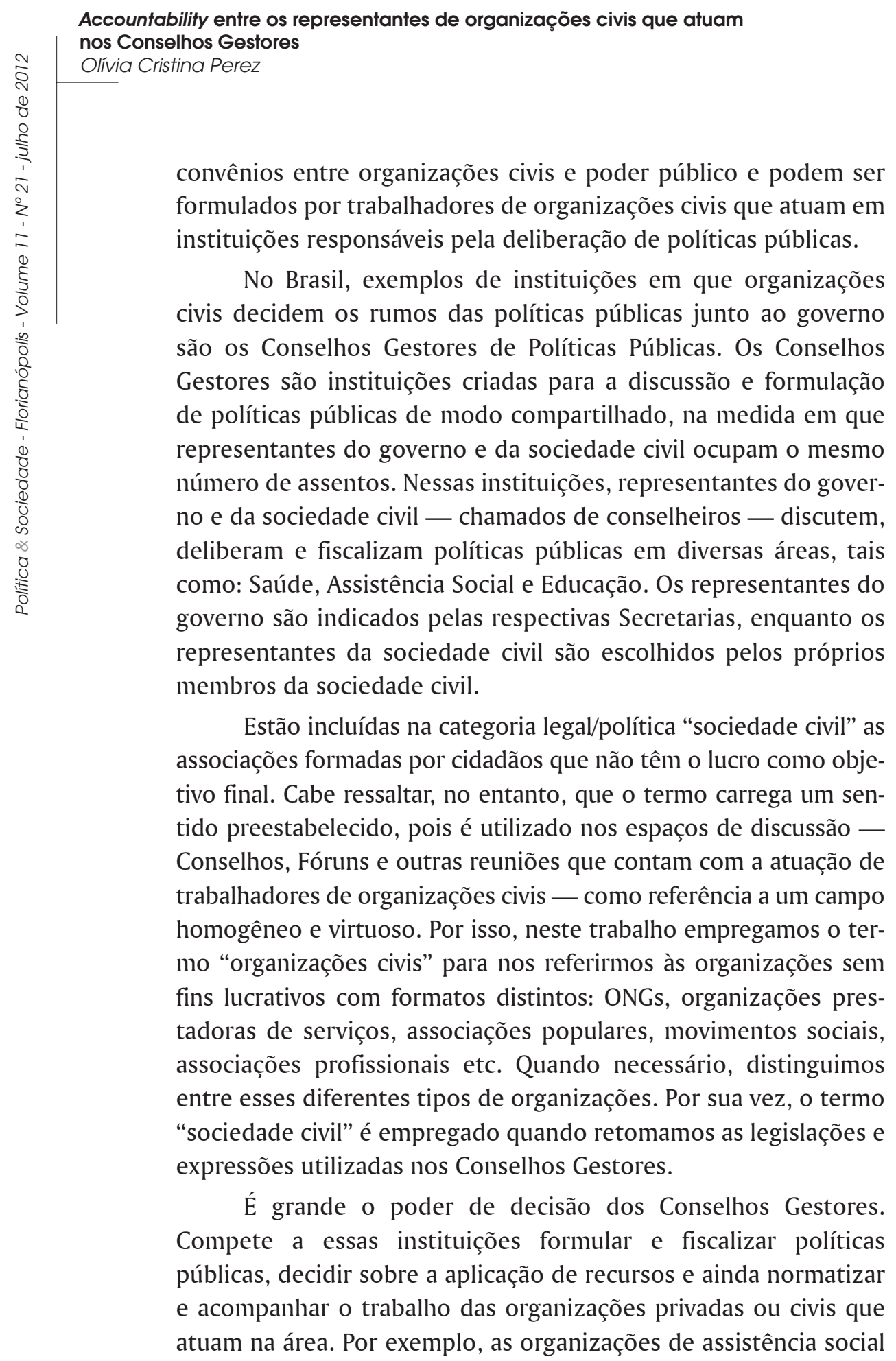


dependem da aprovação do Conselho de Assistência Social para ter suas atividades regulamentadas. Só assim tais organizações podem receber verbas públicas, além disso, as normas para suas atividades são definidas pelos Conselhos.

Ao determinar que as organizações civis devam atuar com o governo, os Conselhos Gestores incluem uma parcela da população na confecção de políticas públicas, concretizando assim as orientações da Constituição de 1988, especificamente as definições sobre a Saúde (Art. 198) e Assistência Social (Art. 204) que determinam a participação da população ou da comunidade na formulação e no controle das políticas públicas. Principalmente por esses motivos, tais experiências são consideradas formas de se concretizar o ideal da democratização da esfera pública, na medida em que os cidadãos podem participar da formulação de políticas governamentais (cf. SANTOS, 2002).

Contudo, pesquisas recentes revelaram que os Conselhos Gestores não são espaços de participação e sim de representação. Os cidadãos não participam diretamente das discussões travadas nos Conselhos, mas são representados por trabalhadores de organizações civis (cf. GURZA LAVALLE; HOUTZAGER; CASTELLO, 2006).

As práticas de representação exercida pelas organizações civis têm sido chamadas de não eleitorais - non-electoral (CASTIGLIONE; WARREN, 2006), autoautorizadas - self-authorized (URBINATI; WARREN, 2008) ou presuntivas (GURZA LAVALLE; HOUTZAGER; CASTELLO, 2006), pois os representantes não foram necessariamente autorizados por meio do processo eleitoral consagrado. Ou seja, nem os membros das organizações civis foram necessariamente escolhidos pelos grupos que representam, nem as próprias organizações passaram pelo processo consagrado de autorização, qual seja: a eleição por um número significativo de votantes circunscritos geograficamente.

Logo, os critérios de legitimidade próprios à representação eleitoral não são visíveis no universo dessas organizações, o que desperta críticas em relação às atividades por elas desempenhadas. Przeworski (2002), por exemplo, considera que as organizações 


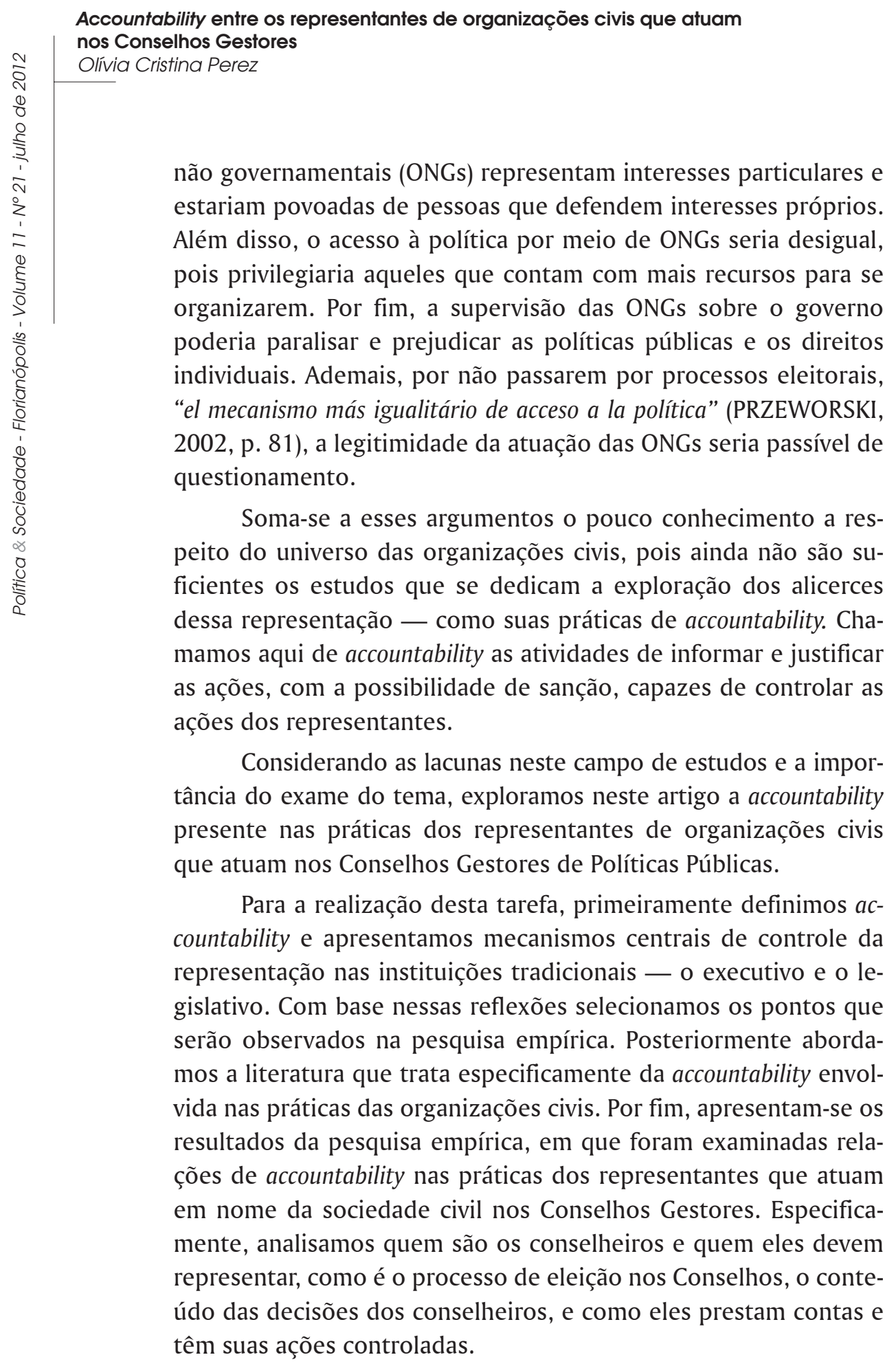




\section{Accountability no governo representativo}

Os regimes representativos modernos carregam diversos ideais de funcionamento, como a existência de certa concordância entre as decisões dos representantes e os anseios daqueles que representam. Segundo o ideal de representação política, os representantes não precisam obedecer às instruções dos seus representados, mas devem ser responsivos, isto é, devem ser sensíveis e responder às demandas daqueles que representam (PITKIN, [1967] 1985). Considerando a centralidade da responsividade para a compreensão da representação, abordaremos como são as decisões dos trabalhadores que atuam nos Conselhos Gestores - objetos da presente pesquisa.

Para o cumprimento dos ideais embutidos no conceito de representação, os governos modernos contam com mecanismos e instituições que estimulam a accountability dos representantes. A accountability dos representantes é capaz de diminuir o hiato entre representantes e representados nas democracias modernas (ARATO, 2002); e é o principal elemento que assegura um bom governo (ACKERMAN, 2004, p. 448).

A palavra accountability tem origem no verbo inglês account, que significa narrar, enumerar, responder para alguém. Não há tradução exata no português. Por vezes encontramos accountability como sinônimo de transparência, responsabilidade ou controle. Também é comum encontrarmos o termo associado à responsividade (a sensibilidade e resposta dos representantes em relação às demandas dos representados) ou à prestação de contas (as informações e justificativas fornecidas pelos representantes sobre suas ações). O conceito não se resume a nenhuma dessas definições, abarcando, no entanto, todas elas. Accountability inclui as atividades de informar e justificar as ações, com a possibilidade de sanção. Por conseguinte, a accountability não é só uma forma de controle, mas inclui normas obrigatórias para que os representantes informem e justifiquem suas ações, sob pena de serem punidos, isto é: 


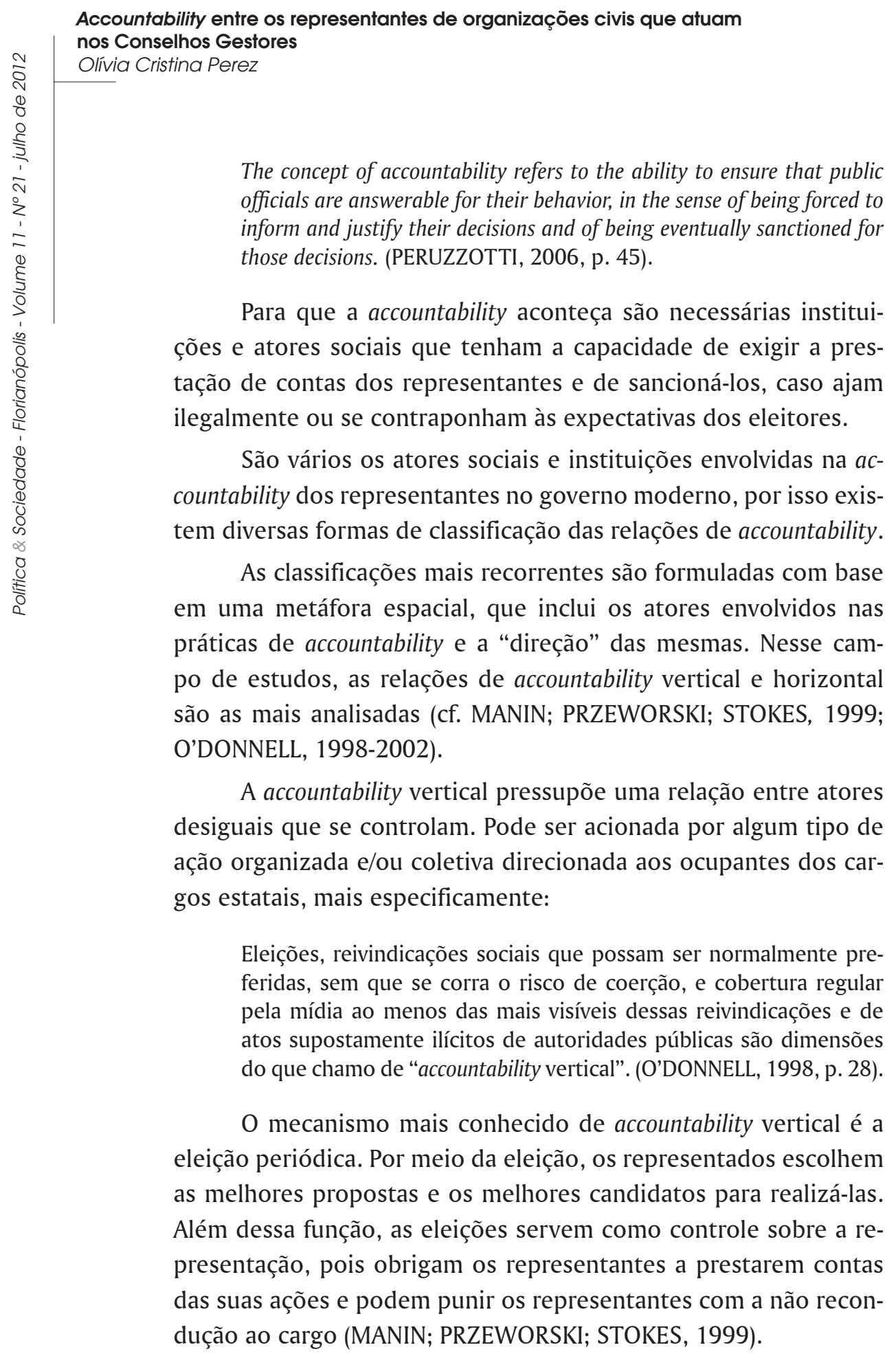


Dessa forma, as eleições estimulam os representantes a agirem de modo responsivo. A garantia de certa concordância entre os interesses dos eleitores e as atitudes dos eleitos acontece porque os políticos foram selecionados segundo propostas de campanha e também porque os eleitos pensam antecipadamente no julgamento dos eleitores, escolhendo, por consequência, políticas que serão avaliadas positivamente nas próximas eleições (MANIN; PRZEWORSKI; STOKES, 1999).

Em suma, de um lado os representantes sabem que estarão sujeitos ao teste das reeleições e por isso levam em conta os interesses dos representados; de outro, os eleitores reelegem os representantes que agiram em favor dos seus interesses. Por conta dessas relações o processo eleitoral é fundamental para a atenção das demandas dos cidadãos. Por ser esse um mecanismo central de exercício de accountability, o processo eleitoral também será estudado na pesquisa empírica desenvolvida neste artigo.

Todavia, apesar de ser consenso a importância das eleições, trata-se de um mecanismo estruturalmente problemático (MANIN; PRZEWORSKI; STOKES, 1999; ACKERMAN, 2004). O processo eleitoral não garante responsividade, pois os candidatos eleitos não decidem necessariamente segundo a campanha eleitoral, considerando que os políticos possuem interesses e valores próprios e não há uma determinação legal que os obrigue a cumprir o que foi prometido na campanha. Ademais, os representantes precisam ter flexibilidade para mudar de opinião, devido às mudanças das circunstâncias e pelo aprendizado adquirido na arena de discussões. A possibilidade de reeleição também não garante accountability, posto que os eleitores não possuem informações suficientes sobre o que os políticos fizeram e farão. Portanto, a reeleição não prova que o político foi um bom representante, prova, no máximo, que todos acreditam nisso (MANIN; PRZEWORSKI; STOKES, 1999). Além disso, as eleições impulsionam apenas a accountability dos representantes eleitos, excluindo dessa obrigação os burocratas não eleitos (ACKERMAN, 2004). 


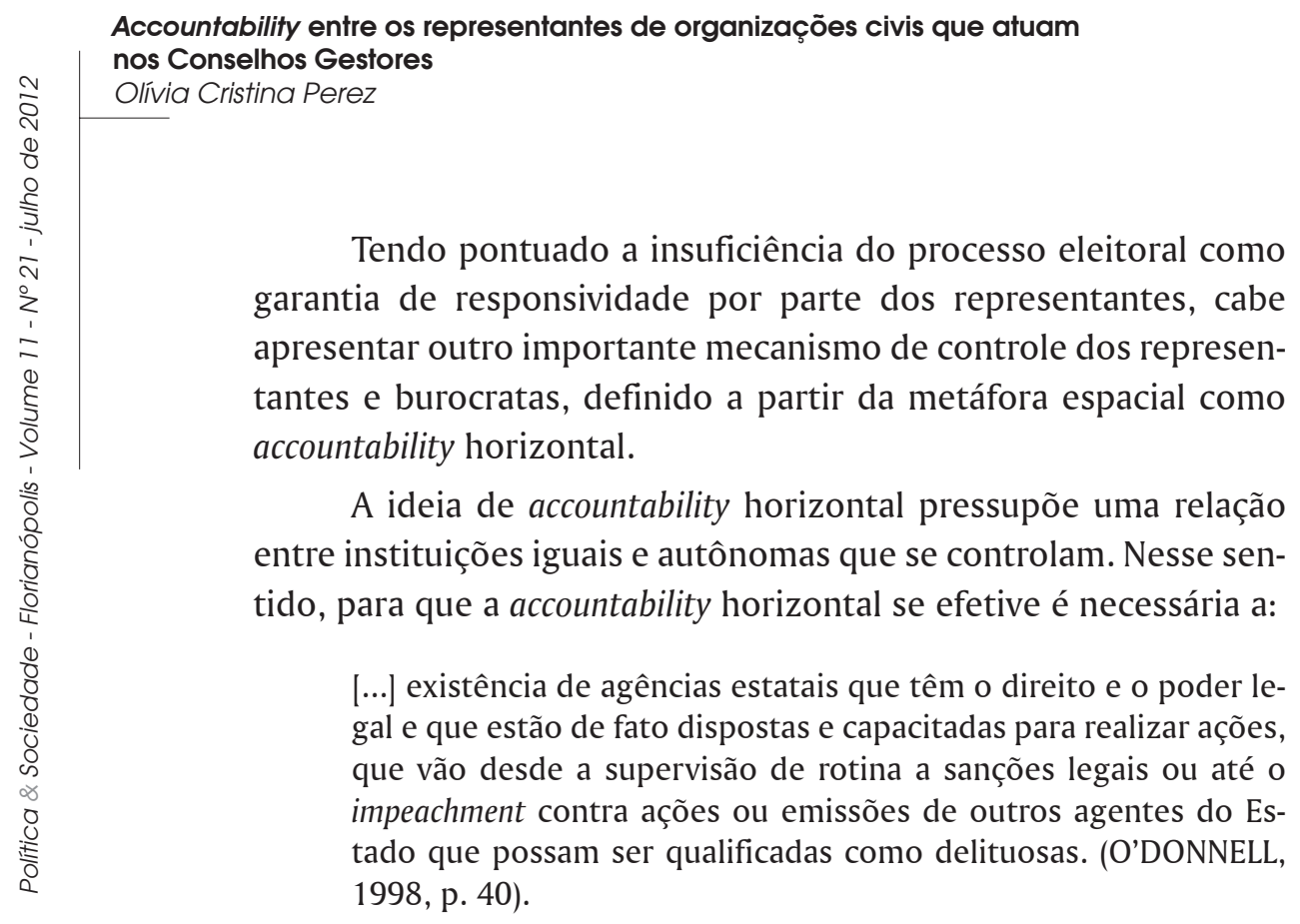

No governo moderno, o principal mecanismo que impulsiona a accountability horizontal é a separação dos poderes executivo, legislativo e judiciário, pois essa separação possibilita o controle entre as instituições do governo. $O$ governo representativo moderno ainda conta com outras instituições responsáveis pelo controle das ações dos políticos eleitos e burocratas, tais como: tribunais, ombudsman e fiscalização.

Devido à importância da accountability horizontal, o exame da mesma pode ser estendido ao estudo da accountability envolvida na prática de trabalhadores de organizações civis, o que será feito na terceira seção do presente trabalho.

\section{Estudos sobre accountability nas organizações civis}

Embora os estudos sobre accountability se concentrem principalmente nas instituições governamentais, já existe uma literatura voltada à análise das práticas de accountability envolvidas nos trabalhos das organizações civis. Essa literatura interessa ao presente trabalho, na medida em que os representantes que atuam 
em arenas extraparlamentares — tais como os Conselhos Gestores de Políticas Públicas — são ligados às organizações civis.

Dentro dessa nova seara de estudos, são comuns os trabalhos a respeito do controle que as organizações civis exercem sobre os administradores públicos (cf. PERUZZOTTI; SMULOVITZ (Eds.), 2002; ACKERMAN, 2004).

O controle sobre os governantes exercido pelas organizações civis e pelos meios de comunicação é definido pela literatura como accountability social (cf. PERUZZOTTI; SMULOVITZ (Eds.), 2002) ou accountability societal (GURZA LAVALLE; ISUNZA VERA, 2010). A accountability social:

[.... es un mecanismo de control vertical, no electoral, de las autoridades políticas basado en las acciones de un amplio espectro de asociaciones y movimientos ciudadanos, así como también en acciones mediáticas. Las iniciativas de estos actores tienen por objeto monitorear el comportamiento de los funcionarios públicos, exponer y denunciar actos ilegales de éstos y activar la operación de agencias horizontales de control. (PERUZZOTTI; SMULOVITZ, 2002, p. 32).

Detalhando melhor, a sociedade civil influencia e monitora as ações do governo por vias institucionais — reclamações a ouvidorias e acionamento da justiça; e vias não institucionais - mobilizações sociais e denúncias pela mídia. Dessa forma, a sociedade civil consegue fazer com que as demandas dos cidadãos sejam ouvidas pelos representantes, que os mesmos prestem contas de suas ações e sejam punidos (PERUZZOTTI; SMULOVITZ, 2002).

Contudo, as organizações civis podem promover a accountability dos representantes parlamentares, mas não serem transparentes com suas bases (FOX, 2006). Por isso é importante observar esse aspecto no universo das organizações civis.

Ademais, como já apontamos, vem crescendo o número de organizações civis que exercem representação política, inclusive junto ao governo em arenas responsáveis pela formulação e fiscalização de políticas públicas, como os Conselhos Gestores. Nesse sentido, deve-se estudar as relações de accountability das organizações civis: 


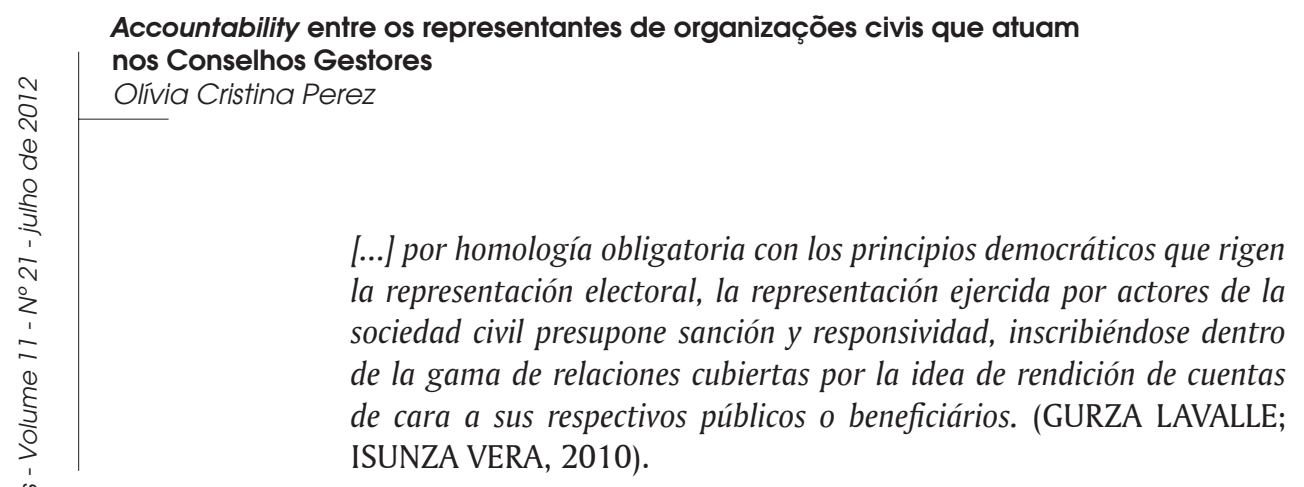

A análise das relações de accountability das organizações civis também é um recorte analítico útil para a compreensão da atuação desses atores. Tal análise permite entender as práticas de representação, mesmo que não tenham sido autorizadas por meio de processos eleitorais consagrados. Ao mesmo tempo, o exame da accountability não dispensa o julgamento da representação não eleitoral, segundo os critérios normativos da representação política. Por fim, o exame da accountability permite a análise das relações das organizações civis com múltiplos atores ao longo do tempo (GURZA LAVALLE; CASTELLO, 2008).

Concretamente, o enfoque na accountability - em especial nas relações das organizações civis sem membros — tem sido cada vez mais adotado pelos estudos que abordam os papéis assumidos pelas organizações civis (cf. JORDAN; TUIJL, 2006; CASTIGLIONE; WARREN, 2006; EBRAHIM; WEISBAND (Eds.), 2007; GURZA LAVALLE; CASTELLO, 2008; GURZA LAVALLE; ISUNZA VERA, 2010).

Os estudos apontam que o formato das organizações civis interfere nas suas relações de accountability. A distinção mais comum na literatura é feita entre as organizações civis com membros — tais como as cooperativas agropecuárias, as sociedades de pesquisa e as associações de aposentados - e as organizações sem membros como algumas ONGs (cf. CASTIGLIONE; WARREN, 2006; PERUZZOTTI, 2006; EBRAHIM, 2007; URBINATI; WARREN, 2008).

As organizações com membros geralmente são accountable aos seus próprios membros. Nelas existe uma relação entre representantes e representados, bem como instâncias e mecanismos de accountability (PERUZZOTTI, 2006, p. 51-52; URBINATI; WARREN, 2008). Os membros podem votar nos líderes da organização, revogar a filiação e o pagamento de taxas, tentar reformar 
a organização influenciando os líderes ou disputando uma posição de liderança (EBRAHIM, 2007, p. 204-207). Essas organizações ainda podem apresentar mecanismos de accountability horizontais, tais como instâncias intermediárias de participação, em que os membros supervisionam o trabalho dos líderes e de outras esferas (FOX, 2006, p. 54).

Logo, é possível traçar um paralelo entre os mecanismos de accountability presentes nas organizações civis com membros, e aqueles que predominam nas arenas parlamentares, pois "[...] la dinamica vertical-horizontal de las políticas de rendición de cuentas en um universo macro, se reproduce de modo análogo en organizaciones de membresía" (FOX, 2006, p. 55).

Assim, os desafios dessas organizações civis em relação à construção de mecanismos de accountability são menores do que aqueles enfrentados pelas outras organizações (EBRAHIM, 2007, p. 204). Esse é o caso das organizações civis sem membros.

Na prática, as organizações civis sem membros desenvolvem relações de accountability com diversos atores envolvidos nos seus trabalhos, ou seja, seus stakeholders (PERUZZOTTI, 2006; EBRAHIM, 2007). Na literatura é comum a distinção entre três tipos de stakeholders: os doadores - organizações privadas, Estado, outras organizações civis e doadores particulares; os trabalhadores e diretores das organizações; e aqueles que são alvo dos seus trabalhos (PERUZZOTTI, 2006). Elas também podem desenvolver relações de accountability com a mídia e com outras organizações civis (KOLINSKI, 2007).

Nesse último caso, as organizações que se juntam em redes ou coalizões - para que somem forças na implementação de suas tarefas - podem desenvolver relações de accountability horizontal entre pares (FOX, 2006; KOLINSKI, 2007, p. 120-121). Também existem relações de accountability entre organizações que não atuam conjuntamente. Isso acontece, por exemplo, quando ONGs, sindicatos e movimentos sociais se reúnem — geralmente em fóruns temáticos - e exigem informações e justificativas sobre o trabalho de outras organizações. 


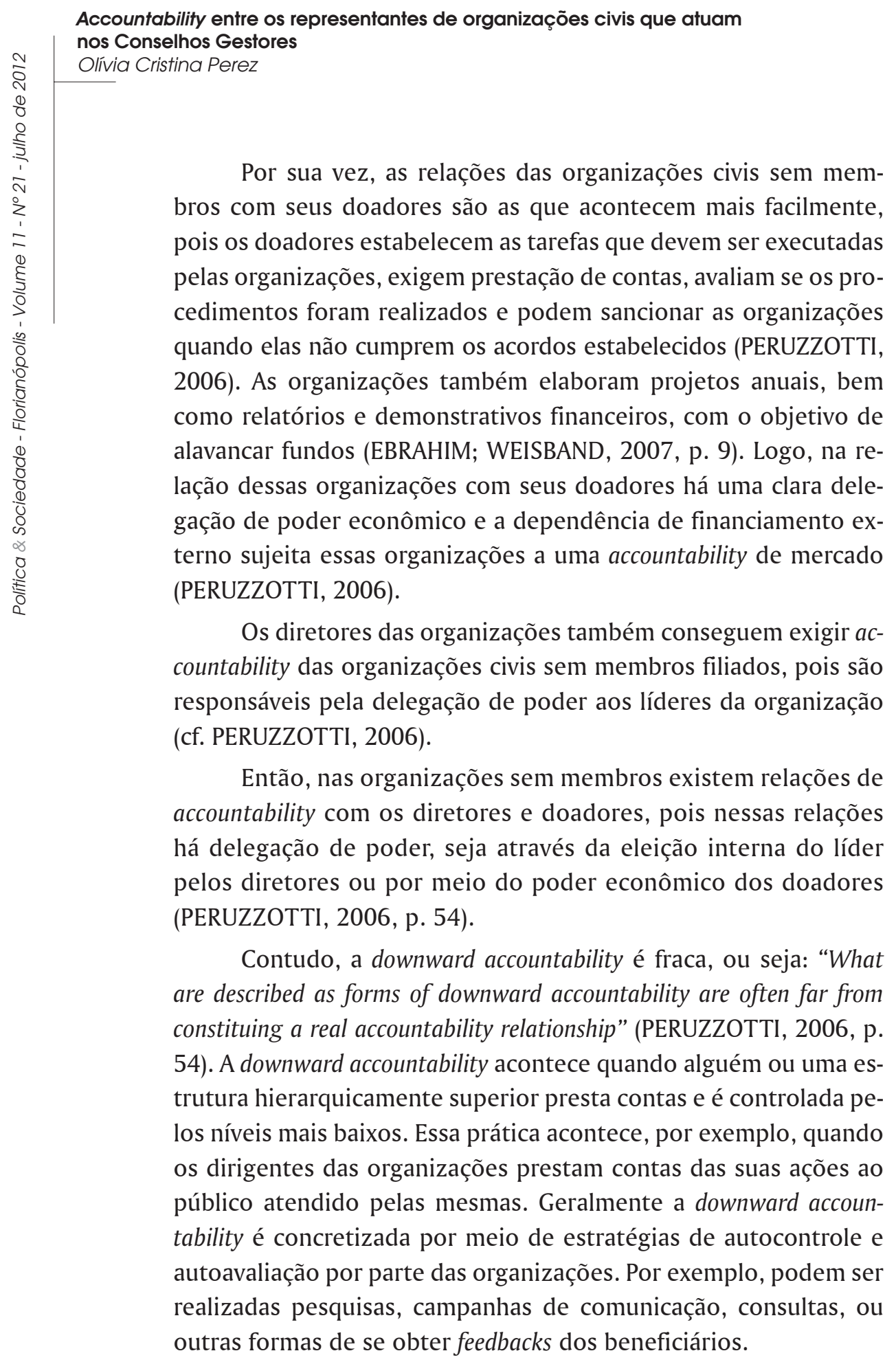


Em muitos casos os cidadãos participam das atividades das organizações civis sem membros (através de contribuições em dinheiro ou trabalho), mas essa participação não beneficia sempre a downward accountability, pois os objetivos dos projetos são definidos pelas organizações e pelos seus principais financiadores, sem a participação dos cidadãos. Então, se a participação dos cidadãos nas suas atividades pode ser considerada fortalecedora da downward accountability, na prática, os cidadãos possuem pouco poder de influência (EBRAHIM, 2007, p. 196).

A falta de desenvolvimento da downward accountability se explica pela forma como o poder é estabelecido entre as organizações civis sem membros e o público que atendem. Não há delegação de poder das bases para tais organizações: são elas mesmas que estão na posição de poder, enquanto os alvos de intervenções dependem dos bens e serviços que as organizações oferecem (PERUZZOTTI, 2006, p. 54). E ainda, os beneficiários dessas organizações são externos a elas, por isso possuem menos poder para moldar as atividades e o direcionamento das organizações sem filiados, ao contrário do que acontece no caso das organizações com membros (EBRAHIM, 2007, p. 204).

Em geral, o desenvolvimento de accountability nas organizações civis sem membros é dificultado pelo próprio formato das organizações, pois: "There is not a clear 'bottom line' for results and no single authority to which NGOs must report on their activities" (MICHAEL EDWARDS, 2000 apud CHARNOVITZ, 2006, p. 28). As relações de accountability de tais organizações podem acontecer em muitas direções: com sua base, com partidos políticos, religiões, financiadores, outras ONGs etc. (FOX, 2006).

As organizações civis sem membros também têm dificuldade para delimitar seu público-alvo. Por exemplo, elas podem lutar por uma causa, como aquelas que defendem o meio ambiente ou a paz. Nesses casos, não há um público específico para o qual as organizações devam ser accountable.

Ademais, a ênfase dominante na accountability das organizações civis sem membros com seus patrocinadores prejudica o 


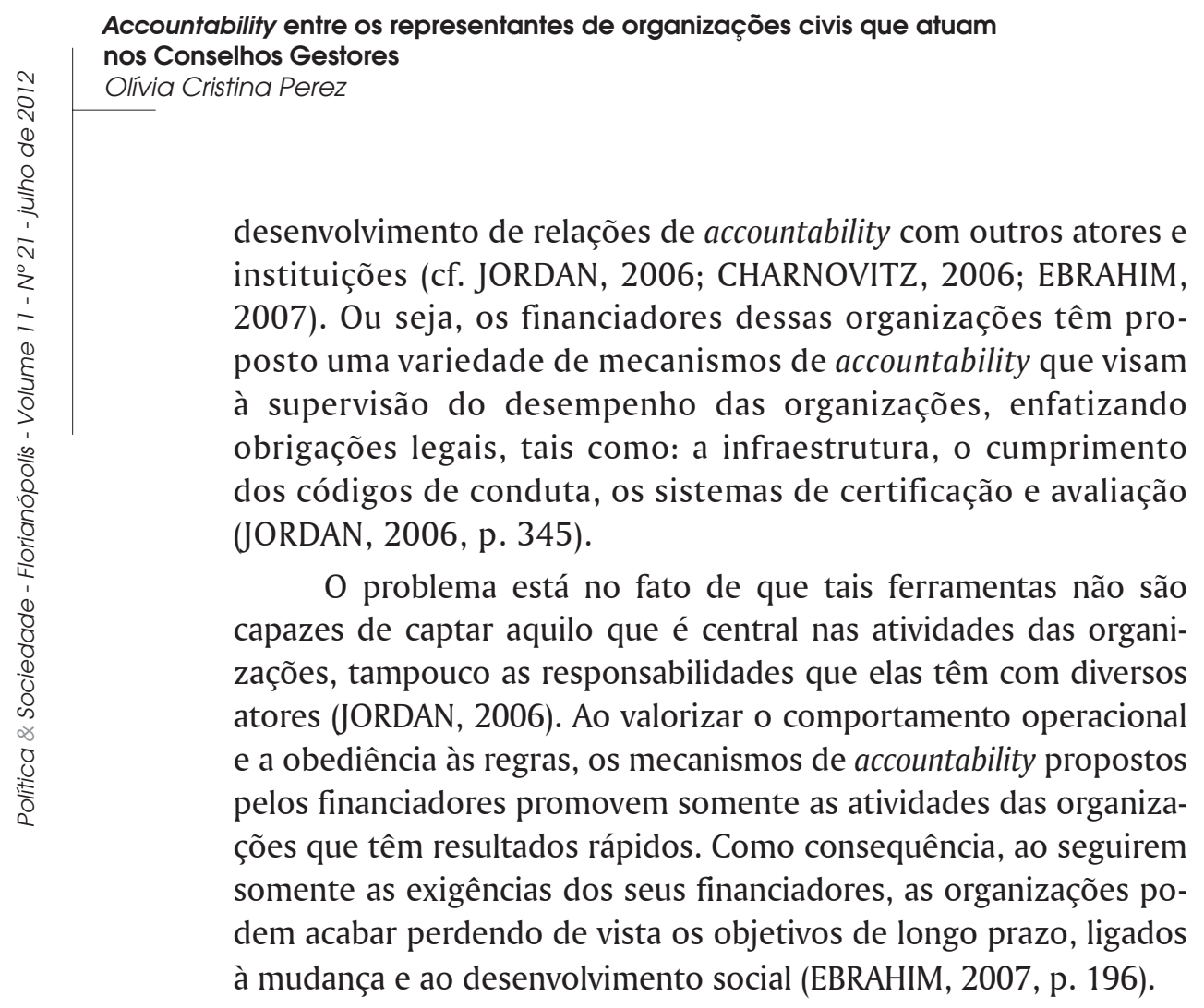

\section{Accountability entre os representantes de organizações civis que atuam nos conselhos gestores}

Apresentamos a seguir os resultados da pesquisa empírica sobre as relações de accountability envolvidas nas práticas dos trabalhadores de organizações civis que atuam como representantes nos Conselhos Gestores de Políticas Públicas.

Para a realização da pesquisa, selecionamos como objeto empírico os representantes que atuavam nas seguintes instituições: Conselho Municipal de Assistência Social de São Paulo (COMAS/SP); Conselho Municipal de Assistência Social de Santo André (CMAS/SA); Conselho Municipal de Saúde de São Paulo (CMS/SP); Conselho Municipal de Saúde de Santo André (CMS/SA).

Mais detalhadamente, entrevistamos três conselheiros da sociedade civil do Conselho Municipal de Assistência Social de 
São Paulo; três do Conselho de Assistência Social de Santo André; cinco representantes da sociedade civil no Conselho Municipal de Saúde de São Paulo; e outros cinco do Conselho de Saúde de Santo André. Os entrevistados trabalhavam em organizações de defesa de direitos; organizações que prestam serviços; associações populares; movimentos sociais e associações profissionais. Conforme foi combinado com os entrevistados, garantimos o sigilo dos seus nomes e das organizações em que trabalham. Para identificarmos os conselheiros, utilizamos as letras A, B, C, D e E, seguidas pelos Conselhos em que atuam.

Adotamos o termo "organizações civis" para nos referirmos a todas as associações formadas por cidadãos e que não têm o lucro como propósito final. Tais organizações possuem objetivos e lógicas de atuação distintas: prestam serviços, promovem os interesses dos seus membros e atuam na defesa de causas ou grupos. Logo, o termo "organizações civis" inclui associações com naturezas diversas.

Quanto aos entrevistados, escolhemos conselheiros de origens diversas, tanto no que concerne aos Conselhos em que atuam, quanto ao formato das organizações em que trabalham. E se assim procedemos, foi para que, através de entrevistas qualitativas, conseguíssemos abarcar diferentes concepções sobre a representação. Ou seja, essa é uma amostra intencional, pois permite analisar a representação em instituições que possuem características distintas.

Primeiramente, os Conselhos de Saúde e de Assistência Social geralmente não discutem os mesmos assuntos nas suas reuniões e reservam as vagas de representantes da sociedade civil para organizações com formatos diferentes. Detalhando melhor, as discussões e decisões dos Conselhos Municipais de Assistência Social se concentram especificamente no credenciamento de organizações assistenciais, enquanto que nas reuniões do Conselho Municipal de Saúde são constantes as denúncias e reivindicações dirigidas aos órgãos governamentais. 


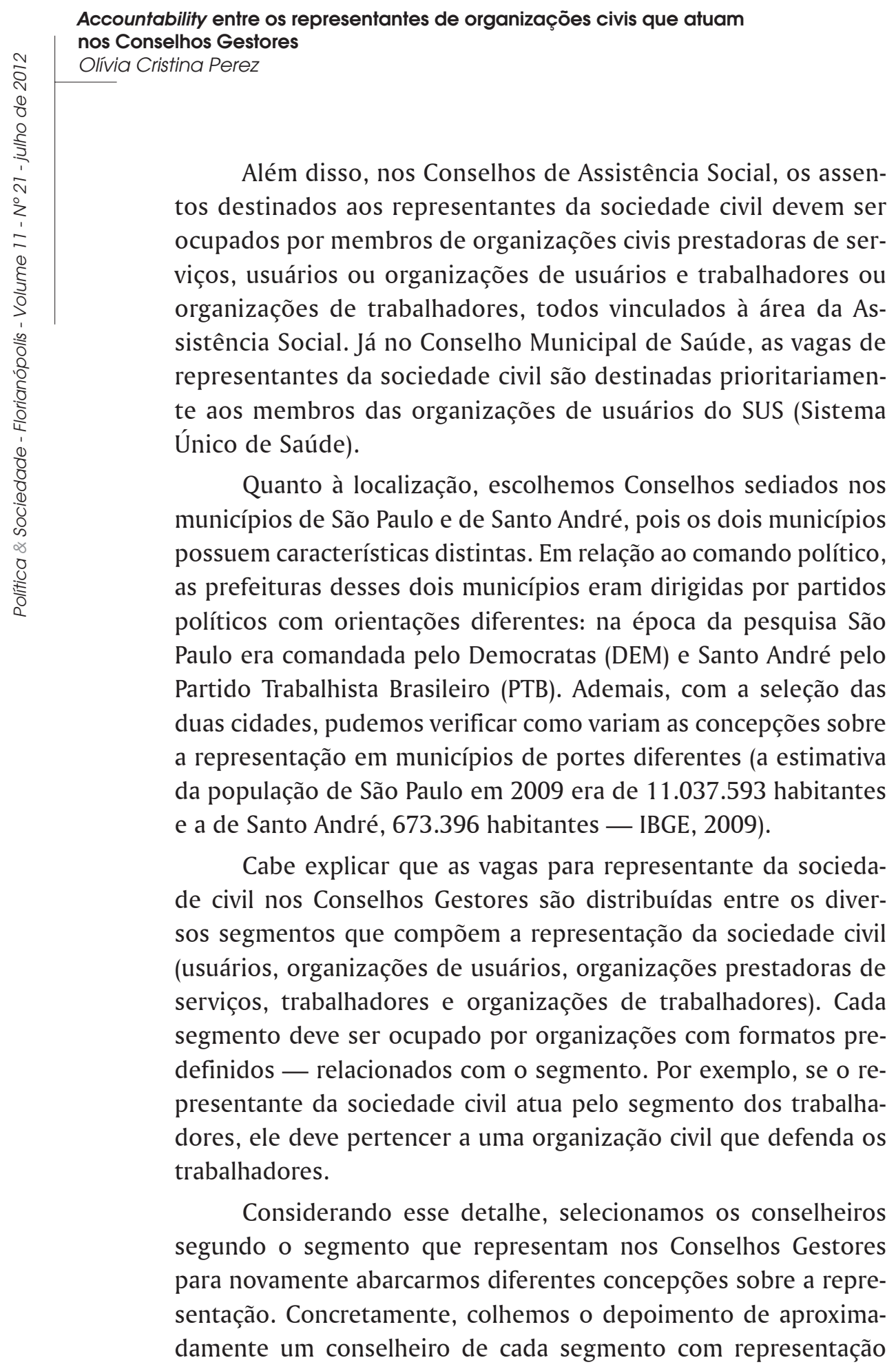


nos Conselhos, dentre aqueles conselheiros que se mostraram mais dispostos para a entrevista.

Especificamente, nos Conselhos Municipais de Assistência Social de São Paulo e de Santo André, são nove os conselheiros da sociedade civil: três representantes dos usuários ou de organizações de usuários, três das entidades e organizações de Assistência Social e três dos trabalhadores do setor. Escolhemos um conselheiro de cada segmento para as entrevistas.

Nos Conselhos de Saúde pesquisados, são dezesseis os conselheiros da sociedade civil, distribuídos entre diversos segmentos: movimentos populares, movimentos sociais, associações de portadores de patologias ou deficiência (organizações de defesa de direitos), organizações prestadoras de serviços, associações profissionais e organizações de usuários. Para as entrevistas, selecionamos conselheiros pertencentes a esses diversos segmentos.

Quanto ao formato das organizações dos conselheiros, um dos entrevistados do COMAS/SP trabalhava em uma organização prestadora de serviços (Conselheiro B do COMAS/SP), outro em associação profissional (Conselheiro $C$ do COMAS/SP) e o terceiro era vinculado a uma organização que prestava serviços na área de assistência social (Conselheiro A do COMAS/SP). No CMAS/SA, dois dos entrevistados atuavam em organizações de defesa de direitos (Conselheiro A do CMAS/SA e Conselheiro C do CMAS/SA) e o terceiro em uma organização prestadora de serviços (Conselheiro $B$ do CMAS/SA). No CMS/SP, um dos entrevistados tinha vínculo com uma associação popular (Conselheira $\mathrm{C}$ do $\mathrm{CMS} / \mathrm{SP}$ ), outro com uma organização de defesa de direitos (Conselheira E do CMS/SP) e três com movimentos sociais (Conselheiro A do CMS/SP, Conselheiro B do CMS/SP, Conselheira D do CMS/SP). No CMS/SA, um entrevistado era ligado a uma organização de defesa de direitos (Conselheiro $\mathrm{B}$ do $\mathrm{CMS} / \mathrm{SA}$ ), dois às organizações prestadoras de serviços (Conselheiro $C$ do CMS/SA e Conselheiro D do CMS/SA) e outros dois às associações profissionais (Conselheira A do CMS/SA e Conselheiro E do CMS/SA). 


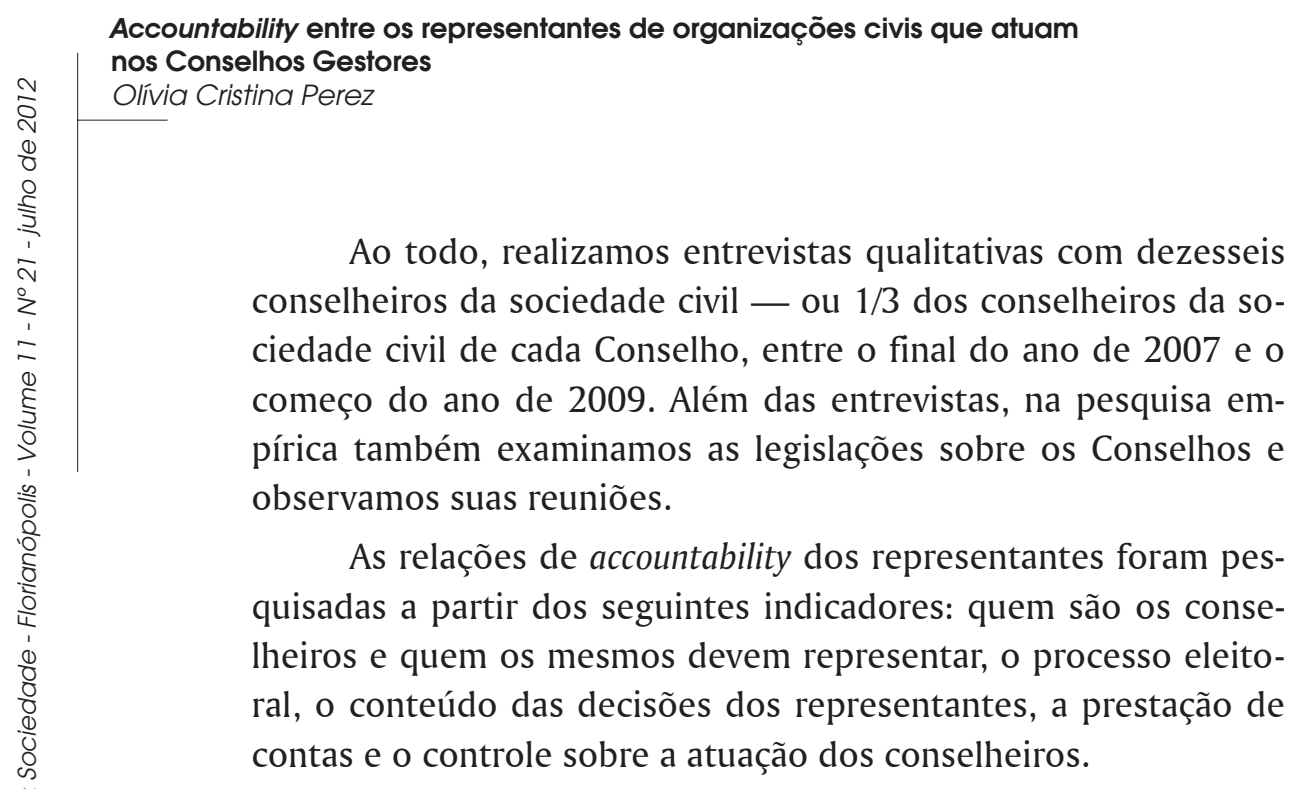

\section{Quem são os conselheiros}

Para compreender a accountability dos representantes que atuam nos Conselhos Gestores, primeiramente esclarecemos como essas instituições são compostas e quais os critérios que regem tal composição.

Os Conselhos Gestores contam com representantes do governo e da sociedade civil que, juntos, decidem sobre políticas públicas. O critério que rege a composição dos Conselhos é formal, pois são as legislações que determinam quem deve ser escolhido para representar a sociedade civil e o governo.

Conforme as legislações, os Conselhos devem ter composição paritária, ou seja, o número de representantes da sociedade civil deve ser o mesmo que o de representantes do governo. Espera-se que com a paridade o poder de decisão dos Conselhos seja partilhado entre os membros do poder público e os representantes da sociedade civil.

Ainda segundo as orientações legais, os conselheiros da sociedade civil devem pertencer às organizações civis. Tais organizações podem ter diferentes formatos: ONGs, organizações de defesa de direitos, organizações prestadoras de serviços, associações 
populares, movimentos sociais, associações profissionais etc. Independentemente do formato, pertencer a uma organização civil da área é precondição para que alguém se candidate a uma vaga de representante da sociedade civil nos Conselhos.

A composição dos Conselhos é detalhada nos seus Decretos de criação e são essas legislações que regem o processo eleitoral nos Conselhos. Os Decretos de criação dos Conselhos Municipais de Assistência Social de São Paulo e de Santo André estipulam que os assentos de representantes da sociedade civil devem ser ocupados pelos usuários ou organizações de usuários; trabalhadores ou organizações de trabalhadores; e organizações prestadoras de serviços, todos da área da Assistência Social.

Por sua vez, os Decretos que tratam dos Conselhos de Saúde de São Paulo e de Santo André incluem as seguintes organizações como representantes da sociedade civil: movimentos populares de Saúde, movimentos sociais, associações de portadores de patologias e deficiência, entidades sindicais gerais patronais e de trabalhadores e entidades de usuários do SUS (Sistema Único de Saúde). Ou seja, somente esses tipos de organizações civis podem ocupar o cargo de representante da sociedade civil nos Conselhos mencionados.

Após serem escolhidas como representantes da sociedade civil, as organizações indicam um dos seus trabalhadores para exercer a função de conselheiro. Ou ainda, os trabalhadores das organizações podem ser escolhidos diretamente, mas os votantes sempre levam em conta a organização à qual o candidato é vinculado.

\section{Quem os conselheiros devem representar}

Já que os conselheiros são formalmente designados "representantes" da sociedade civil segundo as legislações que regem os Conselhos Gestores, cabe esclarecer quem eles devem representar segundo os documentos legais.

As especificações sobre quais segmentos da população devem ser representados nos Conselhos Gestores aparecem apenas 


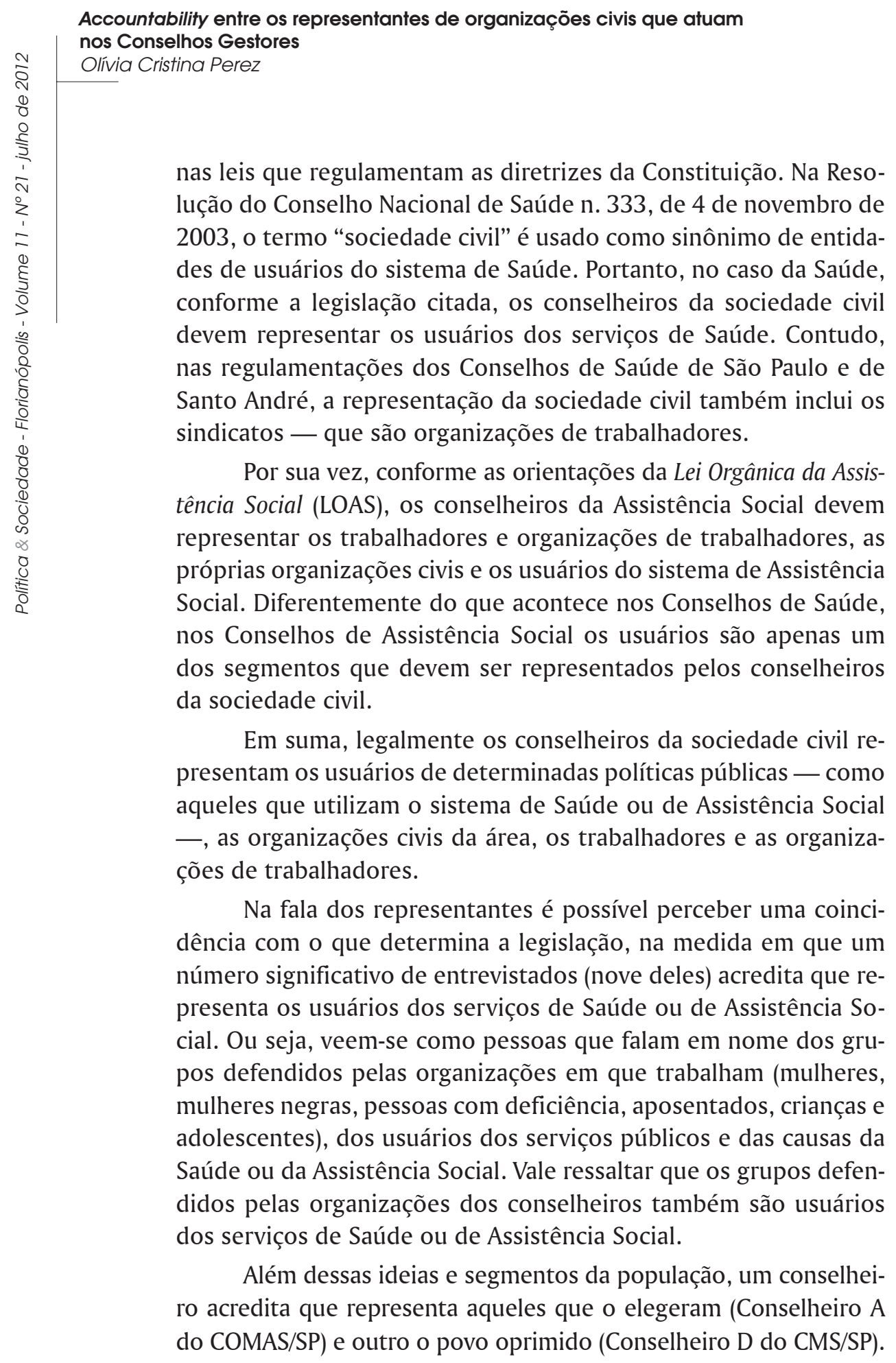




\section{A eleição nos conselhos}

Considerando que a eleição é um mecanismo central de accountability vertical (MANIN; PRZEWORSKI; STOKES, 1999), cabe esclarecer como acontece nos Conselhos Gestores.

Primeiramente, é importante frisar que nos Conselhos Gestores há um processo de autorização. Nesse pleito, os trabalhadores e usuários de determinados serviços votam em militantes de outras organizações civis ou nas próprias organizações candidatas. Quando as organizações civis são as candidatas, as mais votadas indicam um dos seus funcionários para o cargo de conselheiro da sociedade civil.

Não são todos os cidadãos que ficam cientes do processo eleitoral, apenas aqueles que trabalham ou são atendidos por organizações da área do Conselho. Isso porque, em geral, o processo eleitoral dos Conselhos é divulgado nos Diários Oficiais ou pelos conselheiros entre seus colegas de trabalho e em outros espaços de discussão. Por exemplo, o conselheiro $\mathrm{C}$ do $\mathrm{CMS} / \mathrm{SA}$ explicou que a divulgação das eleições:

[...] é no boca a boca mesmo. É pros amigo e companheiro de luta. São eles que vão mesmo [...] A gente divulga no dia a dia. Vai um dia numa reuniãozinha ali, outro dia numa outra ali, articula as pessoas. A massa mesmo não fica sabendo. Não tem propaganda na TV. É diferente. É de quem já tá na luta, entende?²

Logo, somente ficam cientes das eleições as pessoas que têm contato com os conselheiros, que comparecem aos espaços de discussão ou que acompanham os Conselhos.

Para sabermos mais sobre essa questão, acompanhamos o processo de escolha dos representantes nos Conselhos selecionados. O pleito que acompanhamos do Conselho de Assistência Social de São Paulo aconteceu em abril de 2008 e foi realizado em

2 Para a caracterização dos depoentes, transcrevemos as falas dos entrevistados conservando os desvios em relação à norma culta. 


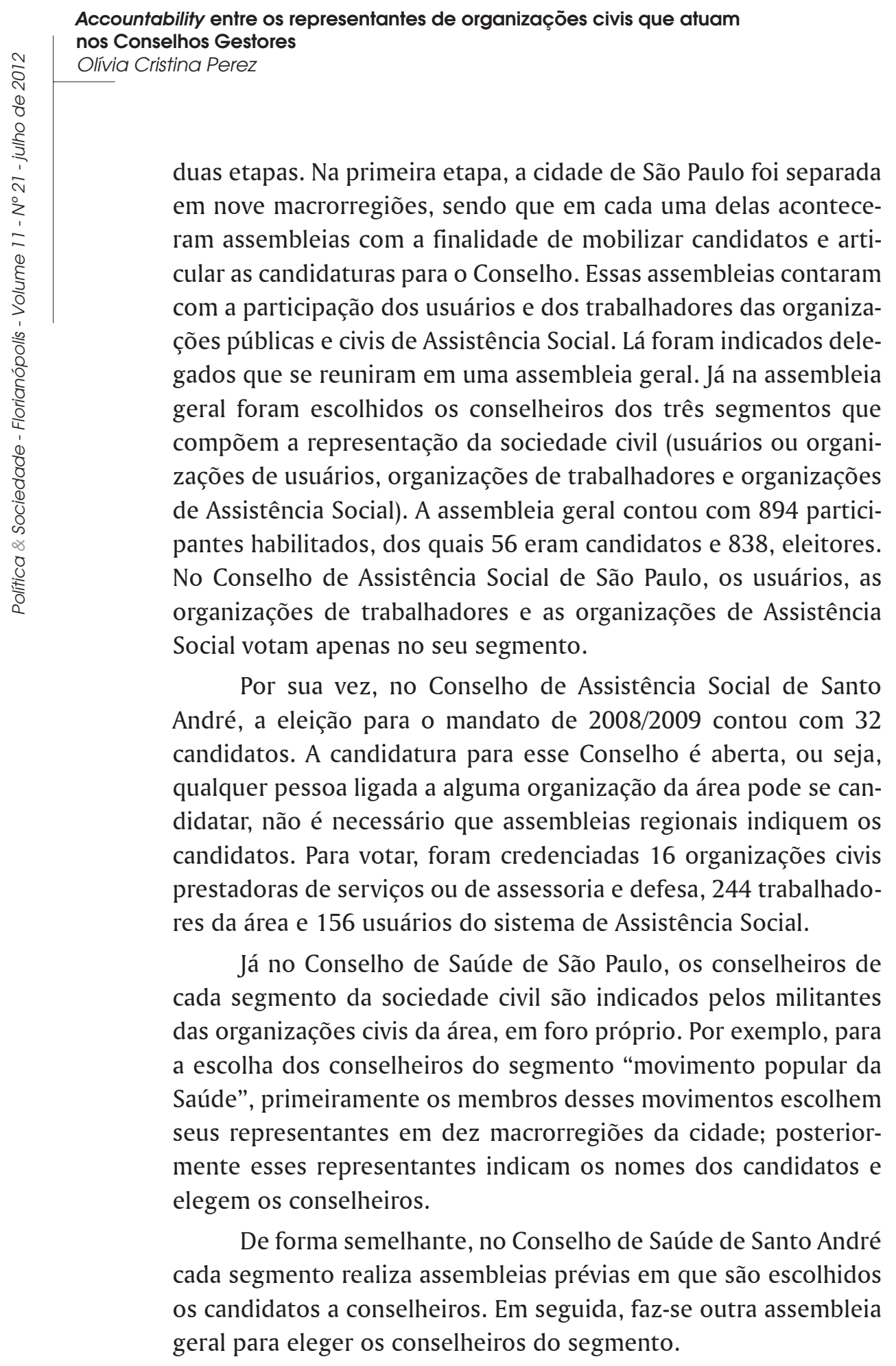


Segundo os entrevistados, quem votou neles na última eleição foram os militantes dos espaços de discussão, os colegas de trabalho e as pessoas atendidas pelas suas organizações. Aliás, nos Conselhos pesquisados, para participar do processo eleitoral tanto os candidatos quanto os votantes são obrigados a apresentar um documento que comprove a ligação com organização civil ou pública da área.

Essas informações confirmam que, assim como a composição dos Conselhos, o processo de autorização é restrito aos trabalhadores ligados às organizações da área. Assim, os trabalhadores de organizações civis são alçados ao posto de representantes por atuarem nas áreas discutidas pelos Conselhos. E, como representantes, votam em outros representantes que decidirão políticas públicas em nome da sociedade civil.

Nesse sentido, a eleição não possibilita que os representados exerçam certo controle sobre seus representantes - como apontaram Manin, Przeworski e Stokes (1999) em relação às arenas parlamentares - já que aqueles que são representados não participam do pleito. São os trabalhadores de organizações civis que ficam cientes do processo eleitoral e votam nas eleições dos Conselhos, influenciando, assim, a representação por meio da eleição.

É de se esperar que os Conselhos Gestores sejam ocupados por militantes ligados às organizações civis. Como demonstramos, nas leis, os Conselhos já são definidos como arenas de representação intermediada por organizações civis, por isso suas regras eleitorais determinam que os candidatos e votantes atuem em organizações da área. Além disso, os trabalhadores de organizações civis têm mais tempo e recursos para comparecerem nessas arenas.

Apesar dessa restrição, os entrevistados decidiram atuar como conselheiros principalmente para contribuir com a melhoria do atendimento oferecido pelos serviços públicos ou para defender as causas da Saúde/Assistência Social. Esse é o argumento da Conselheira D do CMS/SP: 


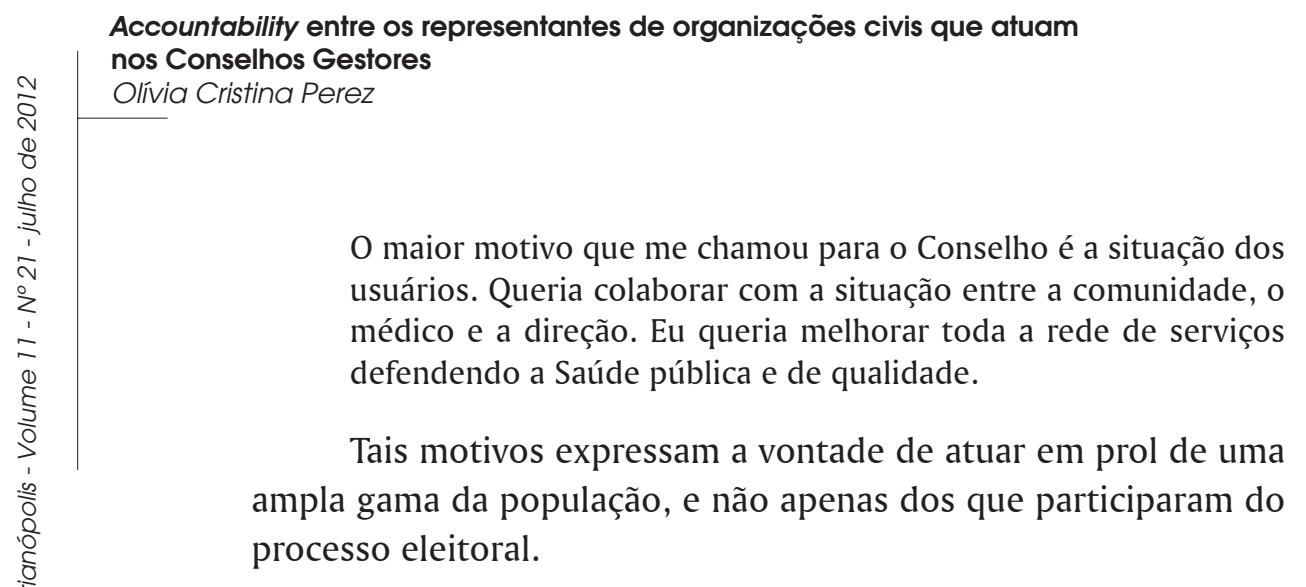

\section{As decisões dos conselheiros}

Outro aspecto central para verificar as relações entre representantes e representados nos Conselhos Gestores trata-se de como são formuladas as decisões dos conselheiros. Essa investigação nos leva a compreender se os representantes são responsivos às demandas daqueles que representam - aspecto central da representação (cf. PITKIN, [1967] 1985).

Constatamos que quatorze conselheiros do total de dezesseis entrevistados tinham propostas sobre o que fazer nos Conselhos, mesmo antes de terem sido eleitos. Todavia, os entrevistados não são obrigados a cumprir essas propostas. Quando as cumprem é por compromisso com os grupos que os ajudaram a formulá-las e por ética pessoal. Essa foi a resposta do conselheiro $\mathrm{C}$ do COMAS/SP:

Antes mesmo de sair candidato, o grupo pensou no que ia fazer pra contribuir com a Assistência. Eu até apresentei as propostas para os colegas. Mas quando entra, aí não precisa botar em prática não. A gente não é obrigado. Eu boto por ética, afinal sou voluntário.

Para decidirem as questões tratadas nos Conselhos, os conselheiros recorrem principalmente à ajuda dos trabalhadores das suas organizações. Foi dessa forma que a conselheira A do CMAS/ SA respondeu à questão:

$\mathrm{Na}$ hora de decidir, eu discuto dentro da entidade, avaliando o que deve ser construído. Junta eu e alguns colegas, e a gente traça um 
plano, colocando na mesa as demandas e o que vamos fazer. É um trabalho em conjunto. Todo mundo senta, analisa direitinho.

Um terço dos entrevistados também formula suas decisões junto aos colegas conselheiros, fóruns, grupos de estudos e com base na opinião pessoal. Todavia, somente os conselheiros da Saúde de São Paulo conversam com os usuários do sistema de Saúde antes de formularem suas decisões. Esse é o caso do conselheiro B do CMS/SP:

Geralmente tento contemplar minimamente os anseios dos usuários, uma vez que é rotineiro discutir com eles em reuniões com grande participação popular. Conversando eu sei o que está acontecendo na real. Eles que têm que me dizer, eles é que sabem.

Em relação aos favorecidos pelas decisões dos conselheiros da sociedade civil, a maioria dos entrevistados acredita que suas decisões beneficiam os interesses dos usuários dos sistemas de Saúde ou de Assistência Social e as demandas da população, enquanto que apenas as decisões de cinco conselheiros - todos de Santo André - contemplam também os interesses das organizações civis. Tais respostas corroboram as legislações dos Conselhos, que preveem que os conselheiros devem representar os usuários das políticas públicas, além de outros segmentos e organizações.

No cotidiano de trabalho, os conselheiros têm contatos mais constantes com os colegas das organizações em que trabalham, com os militantes que frequentam os espaços de discussão e com o público atendido pelas suas organizações. Dentre todos, os conselheiros paulistanos são os que têm mais contatos semanais com esses atores. Por sua vez, alguns conselheiros da Saúde de Santo André só encontram outros ativistas da área nas reuniões mensais do Conselho e não costumam conversar com nenhum usuário dos serviços de Saúde.

Independentemente de terem mais ou menos contatos com os usuários dos serviços públicos, todos os conselheiros consideram que conhecem as demandas daqueles que representam. Para dois deles, o exame das diretrizes legais — as leis da Saúde ou da 


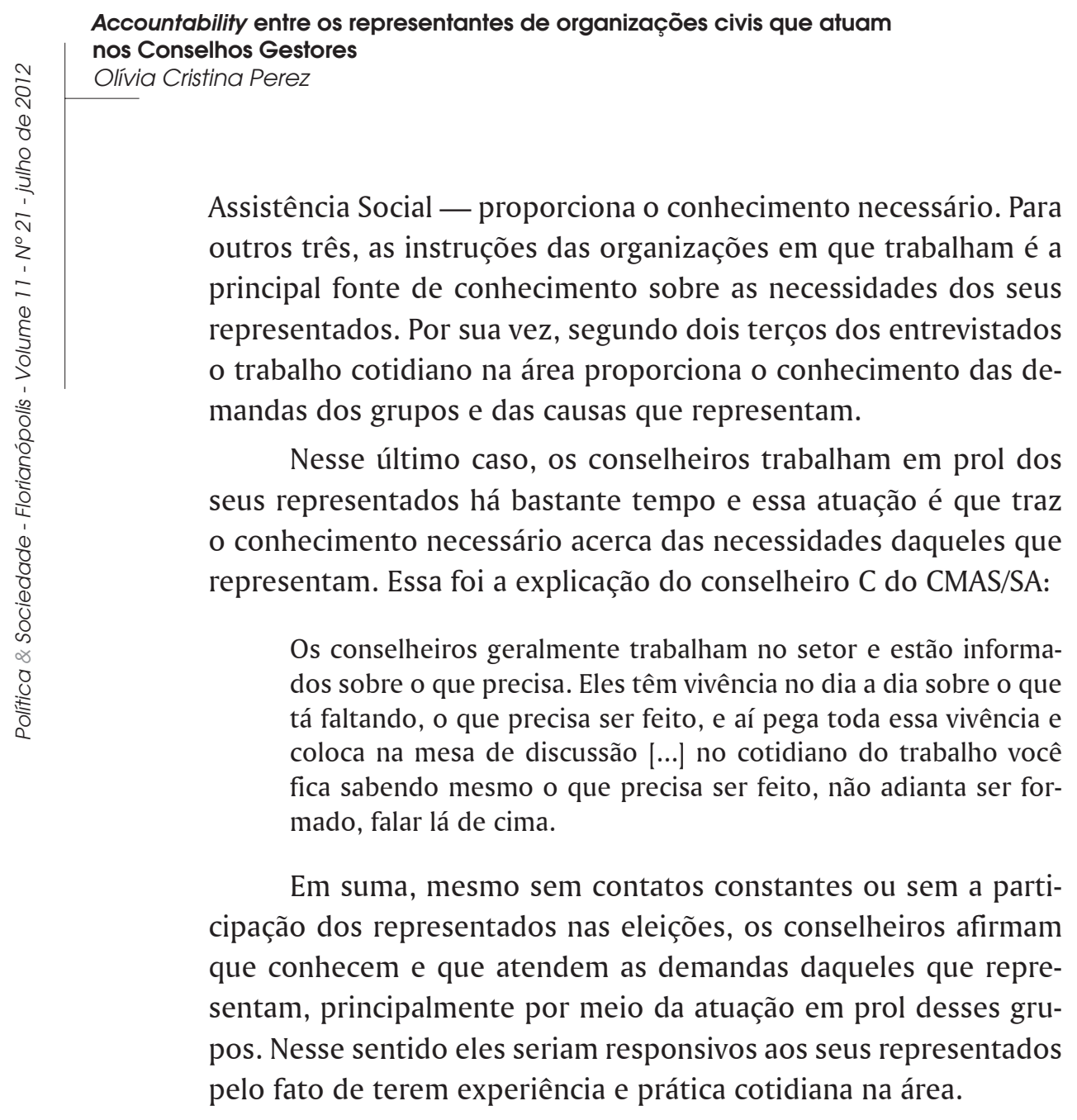

\section{A prestação de contas}

Na pesquisa com os representantes que atuam nem nome da sociedade civil nos Conselhos Gestores também examinamos dois aspectos centrais do conceito de accountability: a prestação de contas por parte dos representantes aos representados e o controle sobre as ações dos primeiros (cf. PERUZZOTTI, 2006).

Quanto à prestação de contas, verificamos que as atividades cotidianas dos Conselhos são divulgadas, principalmente, nos Diários Oficiais dos Municípios e pelos próprios conselheiros, que 
relatam as ações dos Conselhos nos espaços de discussão. Nesse último caso:

O que acontece nos Conselhos é divulgado pelos próprios conselheiros, que vão às reuniões dos Conselhos Gestores e Populares da Saúde. É no boca a boca a divulgação. Pra quem? Pra quem é do movimento (Conselheiro B do CMS/SP).

Embora com menor frequência, as atividades dos Conselhos também são divulgadas pelos jornais de bairros, carros de som e por meio da internet. Não há ampla divulgação sobre os Conselhos para os usuários dos serviços de Assistência Social ou de Saúde, tampouco para as organizações civis que não comparecem aos diversos espaços de discussão.

Os próprios conselheiros divulgam as atividades que realizam nos Conselhos somente aos diretores e colegas das organizações em que atuam e aos trabalhadores de organização civis que comparecem nas reuniões frequentadas por eles.

Em suma, somente os usuários dos serviços públicos e os trabalhadores de organizações que comparecem nos espaços de discussão ou que possuem colegas conselheiros são informados diretamente sobre as ações dos seus representantes. Noutras palavras, apenas aqueles que estão incluídos nesse universo são informados sobre o andamento dos Conselhos.

Daí decorre que há prestação de contas por parte dos conselheiros, na medida em que os mesmos informam as atividades desempenhadas e justificam suas ações para seus colegas de profissão.

\section{O controle da representação}

No tocante à existência e à forma como as atividades dos conselheiros são controladas, observamos que para um terço dos entrevistados não existe controle sobre as atividades que desenvolvem nos Conselhos. Os outros dois terços explicaram que os diretores e colegas das organizações em que trabalham, os trabalhadores da 


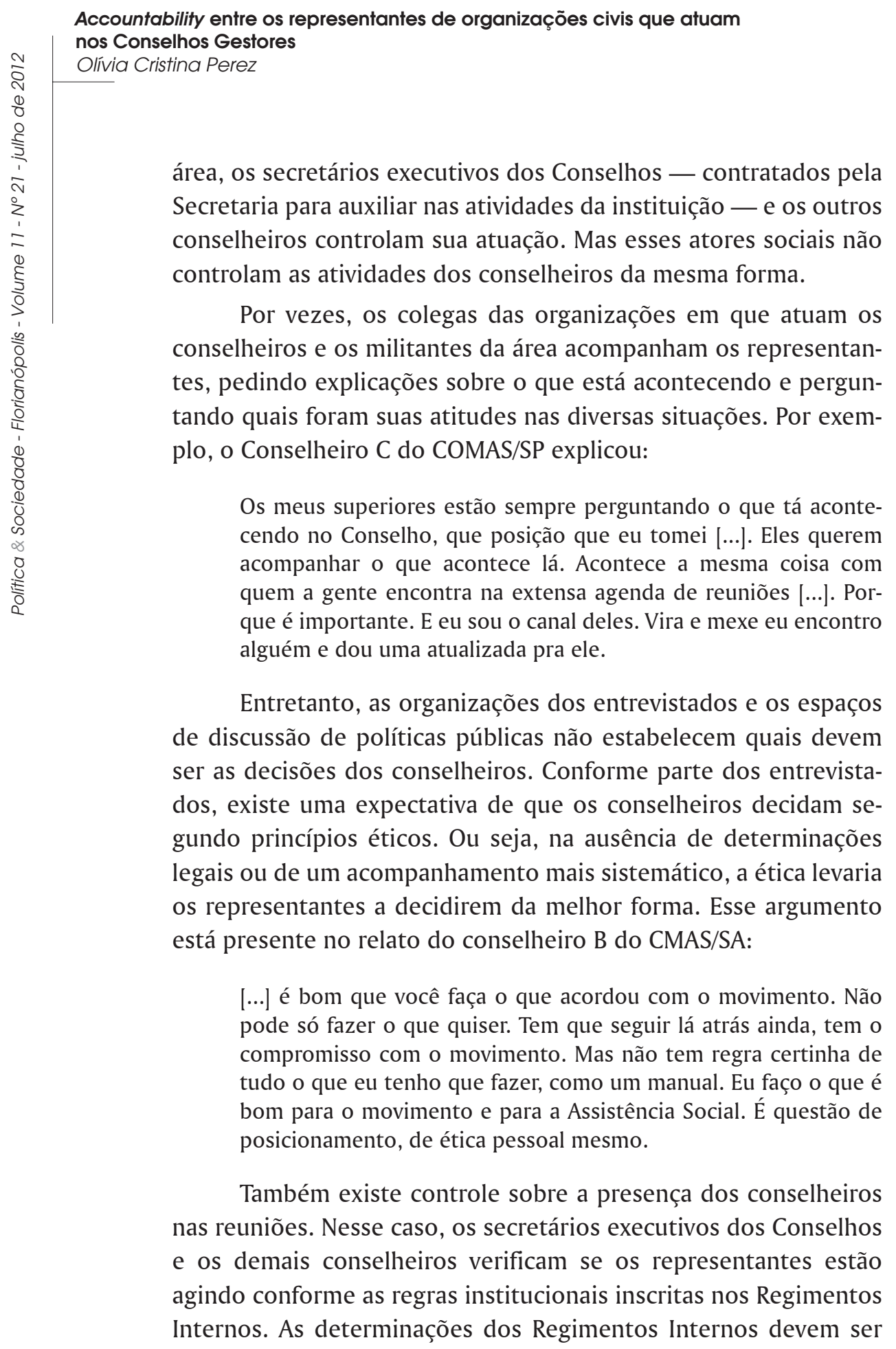


seguidas, pois, caso os conselheiros deixem de cumpri-las, podem ser destituídos dos seus postos. Contudo, os Regimentos Internos estipulam basicamente a frequência dos conselheiros às reuniões. Para esclarecer essa obrigação, a Conselheira A do CMAS/SA explicou:

$\mathrm{O}$ que o conselheiro tem que fazer mesmo é estar em todas as reuniões. Não pode faltar [...]. E quem controla isso? A secretária do Conselho. E se o conselheiro faltar várias vezes seguidas, entra o suplente. Então tem que ir às reuniões. Tem sempre alguém de olho na gente.

Logo, não existem acordos preestabelecidos que obriguem os conselheiros a prestarem contas das suas ações, que determinem como devem ser as decisões desses representantes ou que estabeleçam punições para quando agirem incorretamente.

No entanto, há controles mais informais sobre as atividades dos representantes, exercidos pelos diretores e colegas das organizações em que trabalham e trabalhadores da área. Esses constrangimentos informais podem ser definidos como um controle horizontal estabelecido principalmente entre pares.

\section{Considerações finais}

Abordamos neste artigo as práticas de accountability de trabalhadores de organizações civis, especificamente daqueles que atuam como representantes em instituições de cogestão denominadas Conselhos Gestores.

Para tanto, investigamos aspectos centrais das relações de accountability: quem são os representantes e quem eles representam, como formulam suas decisões, prestam contas de suas ações e têm suas atividades controladas.

Constatamos que os Conselhos Gestores contam com representantes da sociedade civil e do governo que, juntos, decidem questões importantes, tais como: os contornos das políticas públicas, a aplicação de recursos e a certificação de organizações civis. 


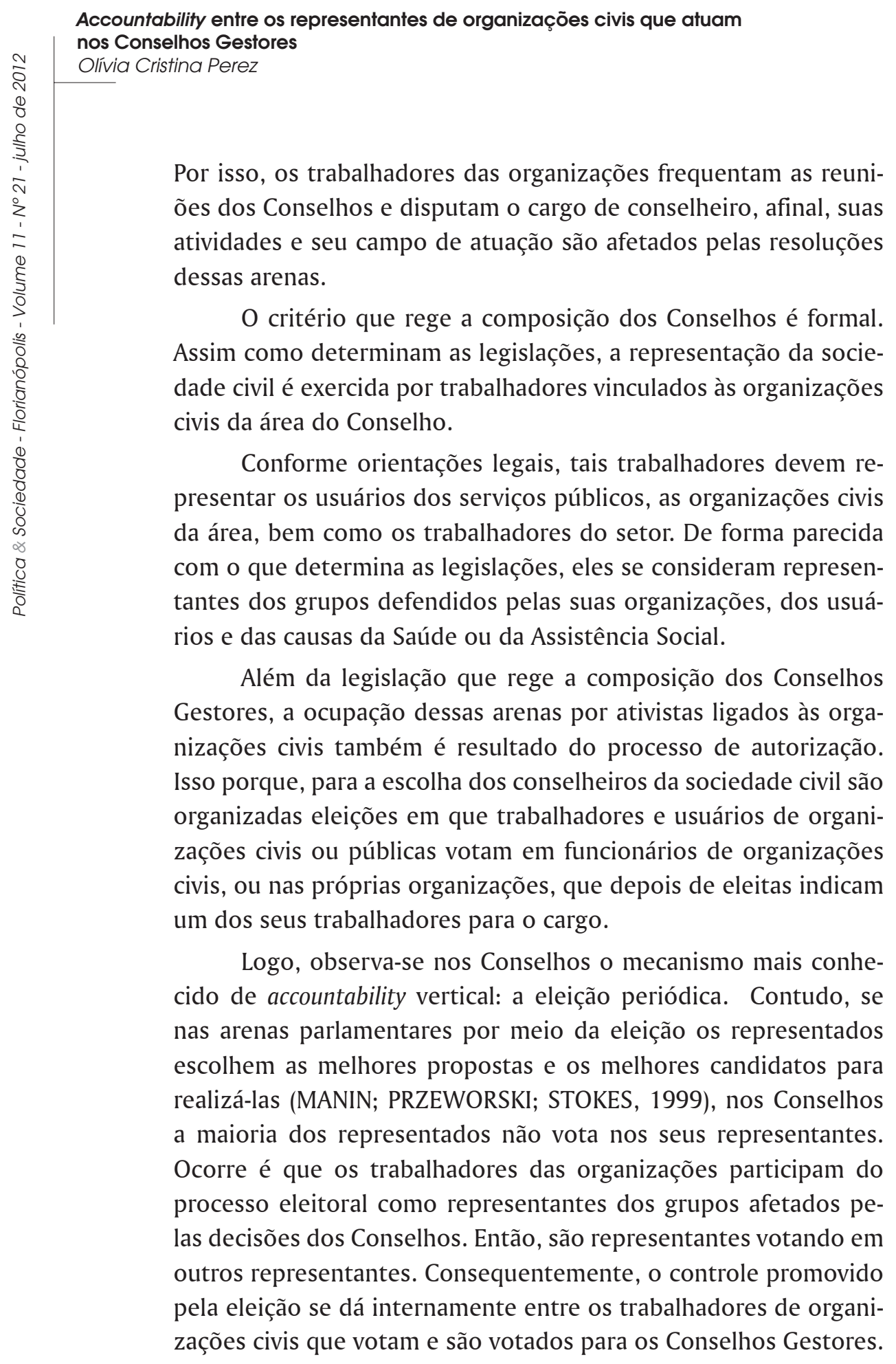


Posto que foram eleitos por um processo restrito às organizações civis, é de se esperar que os conselheiros formulem suas decisões principalmente junto aos colegas das organizações em que trabalham e após conversarem com outros conselheiros. Ou seja, o conteúdo das decisões dos conselheiros geralmente é formulado no âmbito das organizações civis e do próprio Conselho. Mesmo assim eles afirmam que sabem das demandas dos seus representados, já que atuam em prol daqueles que representam nas suas organizações. Desse modo, atuar com os grupos representados nos Conselhos confere aos trabalhadores das organizações civis conhecimento sobre a causa e legitimidade à prática de representação.

Assim sendo, a responsividade, ou seja, a capacidade de o representante responder às demandas daqueles que representa (PITKIN, [1967] 1985) estaria presente nas práticas dos representantes que atuam nos Conselhos Gestores, na medida em que os mesmos atuam em prol das demandas daqueles que representam não só nos Conselhos, mas também no cotidiano profissional das organizações em que atuam. Noutras palavras, os conselheiros conhecem e atendem as demandas daqueles que representam porque trabalham em prol dessas ideias e segmentos da população.

São poucos os atores sociais cientes das ações dos conselheiros. Tais representantes informam somente os diretores e colegas das organizações em que atuam e os militantes dos espaços de discussão que frequentam sobre suas atividades. E são esses mesmos atores sociais que, por vezes, acompanham as atividades dos representantes, enquanto os Conselhos verificam a presença dos conselheiros nas reuniões.

A prestação de contas e o controle sobre as ações dos conselheiros acontecem internamente entre os trabalhadores de organizações civis que se consideram e foram alçados a representantes por possuírem experiência na área. Ou seja, as relações de accountability desenvolvem-se entre trabalhadores que atuam com os grupos sociais afetados pelas decisões dos Conselhos. 


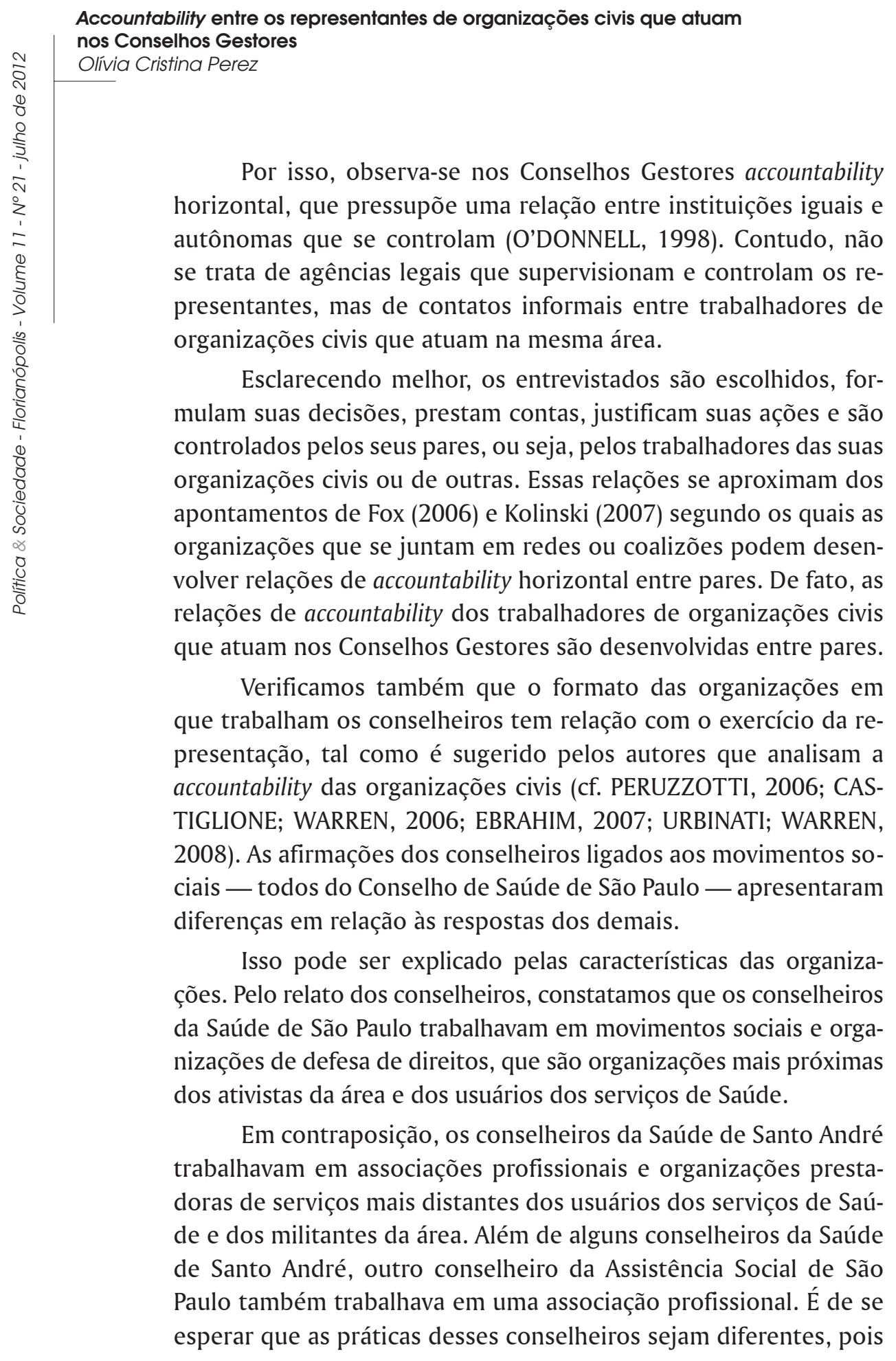


as associações profissionais defendem os trabalhadores da área e não os usuários dos serviços públicos. Ademais, o trabalho deles nessas organizações era mais técnico, por isso tais conselheiros tinham menos contato com os usuários e ativistas da área.

Em suma, nos Conselhos Gestores o processo de eleição não garante contato entre representados e representantes e, consequentemente, accountability por parte dos representantes, assim como nas arenas parlamentares. Ademais, os conselheiros não prestam contas ou são controlados diretamente pelos seus representados e não há instituições ou acordos formais que controlem suas decisões. A accountability acontece de forma horizontal entre pares, ou seja, entre os próprios trabalhadores de organizações civis que atuam na mesma área. São esses que votam nos conselheiros, ajudam na formulação das decisões, são informados das ações dos representantes e controlam informalmente as mesmas.

Logo, tais instituições construíram novos critérios de accountability, na medida em que o cargo de representante, a formulação de decisões, a prestação de contas e o controle da representação são restritos aos trabalhadores de organizações civis que atuam e conhecem sobre a área discutida em cada Conselho.

\section{Referências}

ACKERMAN, J. Co-Governance for Accountability: Beyond "Exit" and "Voice". World Development, v. 32, n. 3, 2004. p. 447-463.

ARATO, A. Representação, Soberania Popular e Accountability. Lua Nova, n. 55-56. São Paulo: 2002. p. 85-103.

BRASIL. Constituição da República Federativa do Brasil de 5 de outubro de 1988. São Paulo: Atlas, 2004.

. Lei n. 8.742, de 7 de dezembro de 1993. Lei Orgânica da Assistência Social. 


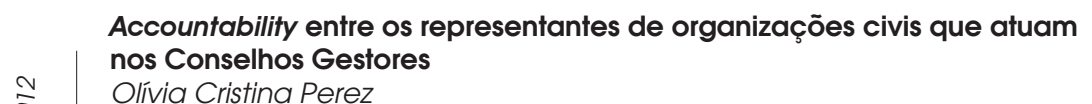

Olivia Cristina Perez

. Resolução do Conselho Nacional de Saúde n. 333, de 4 de novembro de 2003. Aprova as diretrizes para criação, reformulação, estruturação e funcionamento dos Conselhos de Saúde.

CASTIGLIONE, D.; WARREN, M. Rethinking Democratic Representation: Eight Theoretical Issues. Trabalho apresentado no Workshop Rethinking Democratic Representation. University of British Columbia, 18-19 de maio, 2006.

CHARNOVITZ, S. Accountability of Non-Governmental Organizations in Global Governance. In: JORDAN, L.; TUIJL, P. (Eds.). NGO Accountability: politics, principles and innovations. London: Earthscan, 2006. p. 21-42.

EBRAHIM, A. Towards a reflective accountability in NGOs. In: EBRAHIM, A.; WEISBAND, E. (Eds.). Global accountabilities: participation, pluralism, and public ethics. Cambridge: Cambridge University Press, 2007. p. 193-224.

FOX, J. Sociedad civil y políticas de rendición de cuentas. Perfiles Latinoamericanos, n. 27. México: FLACSO, 2006. p. 33-68.

GURZA LAVALLE, A.; HOUTZAGER, P.; CASTELLO, G. Representação política e organizações civis: novas instâncias de mediação e o desafio da legitimidade. Revista Brasileira de Ciências Sociais, n. 60. São Paulo: 2006. p. 43-66. GURZA LAVALLE, A.; CASTELLO, G. Sociedade Civil, Representação e a dupla face da Accountability: cidade do México e São Paulo. CADERNO CRH, v. 21, n. 52. Salvador: jan./abr. 2008. p. 67-86.

GURZA LAVALLE, A.; ISUNZA VERA, E. Precisiones conceptuales para el debate contemporáneo sobre la innovación democrática. In: ISUNZA VERA, E.; GURZA LAVALLE, A. (Coords.). La innovación democrática en América Latina. Tramas y nudos de la representación, la participación y el control social. México: CIESASUniversidad Veracruzana, 2010. p. 17-82.

IBGE. Estimativas das populações residentes, em $1^{0}$ de julho de 2009, segundo os Municípios. Rio de Janeiro: IBGE, 2009. 
JORDAN, L. Nuevas formas de abordar la rendición de cuentas: derechos y contexto. In: ISUNZA VERA, E.; OLVERA, A. (Coords.). Democratización, rendición de cuentas y sociedad civil: participación ciudadana y control social. México: CIESAS-UVMiguel Ángel Porrúa, 2006. p. 345-370.

.; TUIJL, P. Rights and Responsabilities in the Political Landscape of NGO Accountability: Introductions and Overview. In: JORDAN, L.; TUIJL, P. (Eds.). NGO Accountability: Politics, Principles and Innovations. London: Earthscan, 2006. p. 3-20.

KOSLINSKI, M. Um estudo sobre ONGs e suas relações de "Accountability". Tese (Doutorado) - Instituto de Filosofia e Ciências Sociais, Universidade Federal do Rio de Janeiro, Rio de Janeiro, 2007.

MANIN, B.; PRZEWORSKI, A.; STOKES, S. "Introductions" and "Elections and representation". In: PRZEWORSKI, A.; STOKES, S.; MANIN, B. (Eds.). Democracy, Accountability, and representation. Cambridge: Cambridge University Press, 1999. p. 1-54.

O'DONNELL, G. Accountability horizontal e novas poliarquias. Lua Nova, n. 44. São Paulo: 1998. p. 27-54.

. Acerca de várias accountabilities e sus interrelaciones. In: PERUZZOTTI, E.; SMULOVITZ, C. (Eds.). Controlando la política: Ciudadanos y medios en las nuevas democracias latinoamericanas. Buenos Aires: Temas, 2002. p. 87-102.

PERUZZOTTI, E. Civil Society, Representation and Accountability: Restanting Current Debates on the Representativennes and Accountability of Civic Associations. In: JORDAN, L.; TUIJL, P. (Eds.). NGO Accountability: Politics, Principles and Innovations. London: Earthscan, 2006. p. 43-60.

.; SMULOVITZ, C. (Eds.). Controlando la política: Ciudadanos y medios en las nuevas democracias latinoamericanas. Buenos Aires: Temas, 2002. 


\section{Accountability entre os representantes de organizações civis que atuam nos Conselhos Gestores}

Olívia Cristina Perez

PITKIN, H. [1967]. El concepto de representacion. Madrid: Centro de Estudos Constitucionales, 1985.

PRZEWORSKI, A. Accountability social en América Latina y más allá. In: PERUZZOTTI, E.; SMULOVITZ, C. (Eds.). Controlando la política: Ciudadanos y medios en las nuevas democracias latinoamericanas. Buenos Aires: Temas, 2002. p. 73-86.

SANTO ANDRÉ. Decreto n. 14.707, de 12 de novembro de 2001. Regulamenta a Lei n. 7.536, de 23 de setembro de 1997, que criou o Conselho Municipal de Assistência Social e o Fundo Municipal de Assistência Social.

. Lei n. 7.489, de 19 de junho de 1997. Dispõe sobre a Conferência, Conselho Municipal e Conselho Diretor de Saúde.

SANTOS, B. Orçamento Participativo em Porto Alegre: para uma democracia redistributiva. In: SANTOS, B. (Org.). Democratizar a democracia: os caminhos da democracia participativa. Rio de Janeiro: Civilização Brasileira, 2002. p. 455-560.

SÃO PAULO. Decreto n. 38.877, de 21 de dezembro de 1999. Regulamenta a Lei n. 12.524, de $1^{\circ}$ de dezembro de 1997, que dispõe sobre a Criação do Conselho Municipal de Assistência Social.

Decreto n. 38.576, de 5 de novembro de 1999. Trata do Conselho Municipal de Saúde.

URBINATI, N.; WARREN, M. The Concept of Representation in Contemporary Democratic Theory. The Annual Review of Political Science, v. 11, 2008.

\section{Abstract}

Accountability of representatives from civil organizations that operate in the Sectoral Policy Councils

Increasingly, civil society organizations take on tasks of representation, exposing and advocating causes and social groups against the State and 
other institutions. However, the representation practices of workers of civil organizations, including their accountability relationships, are still poorly known. Contributing to the studies in this area, we examine in this article some aspects of the accountability relationships involved in the practices of representatives of civil organizations acting in Sector Policy Councils. We found that there are no formal arrangements or institutions capable of promoting accountability of representatives, similar to those that exist in the parliamentary arenas. However, new forms of accountability are practiced by activists of civil organizations working in areas affected by the decisions of the Councils.

Keywords: Accountability. Representation. Civil organizations. Sector Policy Councils. 
